\title{
Pollination biology and reproduction of Seemannia sylvatica (Kunth) Hanstein (Gesneriaceae) in the Serra da Bodoquena National Park, Mato Grosso do Sul
}

\author{
Eduardo Camargo ${ }^{1}$, Licléia da Cruz Rodrigues ${ }^{1,2}$ \& Andréa Cardoso Araujo ${ }^{1,3}$ \\ ${ }^{1}$ Laboratório de Ecologia, Centro de Ciências Biológicas e da Saúde, \\ Universidade Federal de Mato Grosso do Sul-UFMS, CP 549, CEP 79070-900, Campo Grande, MS, Brasil \\ ${ }^{2}$ Laboratório de Ornitologia, Departamento de Zoologia, Instituto de Ciências Biológicas, \\ Universidade Federal de Minas Gerais-UFMG, CP 486, CEP 31270-901, Belo Horizonte, MG, Brasil \\ ${ }^{3}$ Corresponding author: Andréa Cardoso Araujo, e-mail: andrea.c.araujo@uol.com.br
}

CAMARgo, E., RODRIGUES, L.C. \& ARAUJO, A.C. Pollination biology and reproduction of Seemannia sylvatica (Kunth) Hanstein (Gesneriaceae) in the Serra da Bodoquena National Park, Mato Grosso do Sul. Biota Neotrop. 11(4): http://www.biotaneotropica.org.br/v11n4/en/abstract?article+bn02911042011

\begin{abstract}
In Brazil, the family Gesneriaceae is represented by 23 genera and approximately 200 species. Seemannia sylvatica is an herb that occurs in dense populations in the riverbeds at Serra da Bodoquena. Goals of this study were to report the floral biology (on the first five days of anthesis), as well as to determine the breeding system and the pollinators of S. sylvatica. Data collection was conducted from June 2005 to July 2006 through monthly field trips, lasting for five days. Data on floral biology, breeding system and on the floral visitors were taken from individuals located along a track $2500 \mathrm{~m}$ long, in riparian forest of Salobrinha river. Flowers of S. sylvatica are tubular, red, with no perceptive odor and lasted more than five days (ca. 10 - 20 days in individuals transferred to an urban garden and kept in vases). Seemania sylvatica is protandrous, and the male phase occurred between the first and the fourth days of anthesis, while the female one started in the fifth day. Mean nectar volume secreted was $4.77 \pm 3.2 \mu$, with a significative variation among flowers of different ages. Otherwise, nectar concentration average was $9.71 \pm 4.41 \%$, and did not varied significantly in flowers of different ages. The flowers of S. sylvatica were pollinated mainly by the hummingbirds Phaethornis pretrei and Thalurania furcata, and pierced by the bee Ceratina chloris. The butterfly Parides anchises orbygnianus was considered an occasional pollinator of these flowers. Seemannia sylvatica is selfcompatible, since fruit set occurred on the experiments of spontaneous self-pollination, manual self-pollination, crosspollination and open pollination (control). The protandry, coupled with the pattern of nectar production, characterized by low volume and solute concentration, which induces the pollinators to visit different flowers in a given circuit foraging, act maximizing the likelihood of cross-pollination in S. sylvatica. Moreover, the high proportion of fruit set by autogamy is an important strategy considering that $S$. sylvatica is visited by few species, being pollinated mainly by $P$. pretrei. Therefore, in the absence of these visitors, the formation of fruits may be achieved.
\end{abstract}

Keywords: breeding system, ornithophily, Phaethornis pretrei, protandry, riparian forest.

CAMARGO, E., RODRIGUES, L.C. \& ARAUJO, A.C. Biologia da polinização e reprodução de Seemannia sylvatica (Kunth) Hanstein (Gesneriaceae) no Parque Nacional da Serra da Bodoquena, Mato Grosso do Sul. Biota Neotrop. 11(4): http://www.biotaneotropica.org.br/v11n4/pt/abstract?article+bn02911042011

Resumo: No Brasil, a família Gesneriaceae é representada por 23 gêneros e cerca de 200 espécies. Seemannia sylvatica é uma espécie herbácea que ocorre em densas populações nos leitos de rios da região da Serra da Bodoquena. Os objetivos deste estudo foram conhecer a biologia floral (nos primeiros cinco dias de antese), determinar o sistema reprodutivo e os polinizadores de S. sylvatica. A coleta de dados foi realizada no período de junho de 2005 a julho de 2006 através de viagens mensais a campo, com duração de cinco dias. Dados sobre a biologia floral, o sistema reprodutivo e sobre os visitantes florais foram tomados em indivíduos localizados ao longo de uma trilha de $2500 \mathrm{~m}$ de extensão, em área de mata ciliar do rio Salobrinha. As flores de $S$. sylvatica são tubulosas, vermelhas, inodoras e duram mais de cinco dias (ca. 10 - 20 dias em indivíduos transferidos para jardim e mantidos em vasos). Seemannia sylvatica apresenta protandria, sendo que a fase masculina ocorreu entre o primeiro e o quarto dia de antese e a feminina a partir do quinto dia. $\mathrm{O}$ volume médio de néctar secretado foi de 4,77 $\pm 3,2 \mu$, tendo variado significativamente em flores de diferentes idades. Por outro lado, a concentração média do néctar foi de $9,71 \pm 4,41 \%$, e não houve diferença significativa nas diferentes idades da flor. As flores de S. sylvatica foram polinizadas principalmente pelos beija-flores Phaethornis pretrei e pelas fêmeas de Thalurania furcata, e pilhadas pela abelha Ceratina chloris. A borboleta Parides anchises orbygnianus foi considerada polinizadora ocasional dessas flores. Seemannia sylvatica é autocompatível, havendo formação de frutos nos experimentos de autopolinização espontânea, autopolinização manual, polinização cruzada e controle. A protandria, aliada ao padrão de produção de néctar em S. sylvatica, caracterizado pelo baixo volume e concentração de solutos, que induz os polinizadores a visitarem flores diferentes num dado circuito de forrageamento, agem maximizando a probabilidade de ocorrência da polinização cruzada. Por outro lado, a alta proporção de frutos formados por autogamia é uma estratégia importante tendo em vista que $S$. sylvatica é visitada por poucas espécies, sendo polinizada principalmente por $P$. pretrei. Portanto, na ausência desses visitantes, a formação de frutos pode ser assegurada.

Palavras-chave: sistema reprodutivo, ornitofilia, Phaethornis pretrei, protandria, mata ciliar. 


\section{Introduction}

Pollination is a key process in terrestrial communities, being the first stage in sexual reproduction of plants, and an essential prerequisite for the development of fruits and seeds (Kevan et al. 1990). Plants can offer different floral nutritive substances (pollen, nectar, sweet jelly, oil, stigmatic exudate, floral tissues) and/or non nutritive ones (resin, fragrances), as well could offer brooding, shelter and heat site, for their visitors (Faegri \& van der Pijl 1980, Endress 1994, Sazima et al. 2001, Dafni et al. 2005).

The family Gesneriaceae presents a pantropical distribution, including about 150 genus and 4000 species. In Brazil there are 23 genus and approximately 200 species (Souza \& Lorenzi 2005), that could be pollinated by hummingbirds (Franco \& Buzato 1992, SanMartin-Gajardo \& Sazima 2005a), bees (Steiner 1985, SanMartinGajardo \& Sazima 2004, Gao et al. 2006), or bats (SanMartin-Gajardo \& Sazima 2005b). It is estimated that hummingbirds pollinate about $60 \%$ of Neotropical Gesneriaceae and it is believed that its distribution center coincides with the distribution of these birds (Wiehler 1983). Some Gesneriaceae species have in common, apart from pollination by hummingbirds, protandry (Franco \& Buzato 1992, Lara \& Ornelas 2002, SanMartin-Gajardo \& Sazima 2005a,b). In Brazil there are few studies focusing on pollination biology and breeding system of Gesneriaceae species, being all of them conducted in southeast region (e.g. Franco \& Buzato 1992, SanMartin-Gajardo \& Sazima 2005a,b).

Recently there was a reorganization of the genus from the tribe Gloxinieae and Gloxinia sylvatica (Kunth) Wiehler was synonymized to Seemannia sylvatica (Kunth) Hanstein (Roalson et al. 2005). Seemannia sylvatica is an herbaceous species that occur in dense populations in riverbeds in the region of Serra da Bodoquena (Scremin-Dias et al. 1999). This species is native from Bolivia, Peru and Brazil, and is widely traded for ornamental purposes (Wiehler 1976). Given the scarcity of studies regarding pollination of Gesneriaceae species, as well as the absence of data regarding breeding system and pollination of $S$. sylvatica, the objectives of this study were: i) to report flowering period, floral biology and to define breeding system of $S$. sylvatica and ii) to determine the pollinators of this species in the riparian forest of Salobrinha river, in Serra da Bodoquena National Park.

\section{Material and Methods}

The study was conducted in a population of Seemania sylvatica that occurs distributed on calcareous rocks and peats, located in the riverbeds of the riparian forest of Salobrinha River, Serra da Bodoquena National Park (SBNP). The SBNP is located on the Paraguay River basin, southwestern Mato Grosso do Sul $\left(20^{\circ} 36^{\prime}-\right.$ $21^{\circ} 60^{\prime} \mathrm{S}$ and $\left.56^{\circ} 36^{\prime}-57^{\circ} 60^{\prime} \mathrm{W}\right)$. The climate of the area is the AW type, according to Köppen (1948), with a rainy summer and a dry winter. Locally, climate is influenced by relief, which reduces the temperature. Total rainfall is between 1300 and $1700 \mathrm{~mm}$ per year, with more intense rains in summer, being December the wettest month. The dry season lasts three to four months, extending from May to August (Brasil 1997).

The flowering period of $S$. sylvatica was monitored monthly from July 2005 to July 2006 from individuals occurring along a trail of approximately $2500 \mathrm{~m}$ long, parallel to the riverbed. The study of floral and reproductive biology was conducted in expeditions of five days, from April to July 2006. Information on floral morphology, color of the corolla, time of the beginning of anthesis, changes in the position of the floral structures, as well as presence of odor, stigma receptivity and pollen viability were recorded in 12 flowers bagged in pre-anthesis and followed for five days after flower opening. In each of the five days stigma receptivity was tested in five different flowers with hydrogen peroxide (Dafni et al. 2005), and pollen viability in 25 different flowers, by counting pollen grains colored by carmine solution using the method of cytoplasmic staining (Radford et al. 1974). Measures of the androecium (from the base to the apex of the fillets from the anthers) and gynoecium (from the bottom of the stylus to the surface of the stigma) were performed using a caliper on 12 fresh flowers in the early morning during the first five days of anthesis of the flower. Voucher material of S. sylvatica was deposited in the Herbarium of Universidade Federal de Mato Grosso do Sul (CGMS 17012).

To record the amount of nectar produced daily in flowers of different ages, volume and solute concentration of nectar were measured with the aid of a microsyringe (Hamilton, Nevada, USA, $50 \mu \mathrm{l}$ ) and a pocket refractometer (Atago HSR 500, Japan, 0-32\%), respectively (Galetto \& Bernardello 2005). For these measures, flowers were bagged at pre-anthesis phase. In order to prevent effects of an eventual damage to the nectary at the time of nectar measurements on nectar production, at each sampling day it was used different flowers, from different individuals. Measurements were performed on 5-9 flowers each day, according to the availability of flowers of different ages in the sample period. For measurements of nectar in flowers of two or more days, all the accumulated nectar in the flower was removed and discarded in the late afternoon, so as not to interfere in the measurement of the following morning. Morning measures were made ca. 7:30 AM on flowers of first to fifth day, and afternoon measures were made ca. 4:00 AM on flowers of first to third day. Additional measures of nectar were taken in bagged flowers, open for more than five days. To compare the concentration of solutes and volume of nectar produced between the morning and afternoon it was used a $t$ test. To compare these data between the five sample days, we used an analysis of variance (ANOVA) and a Tukey test "a posteriori".

Reproductive system of $S$. sylvatica was studied through controlled crossings on flowers bagged in the pre-anthesis. The ideal sample designed for each treatment was 25 flowers, however due to limitations in the field (e.g. loss of treated flowers by rain or herbivores) some treatments have different sample sizes. Experiments conducted were: 1$)$ agamospermy $(n=10)$ in previously emasculated flowers; 2) cross-pollination $(n=18)$ in previously emasculated flowers; 3) spontaneous self-pollination; $(\mathrm{n}=22)$ and 4) manual self-pollination $(n=19)$. In addition to these treatments, to evaluate the efficiency of natural pollination, 21 flowers were marked and left with free access to visitors (Dafni et al. 2005). The chi-square test was used to compare fruit set between these treatments. The number of seeds produced per fruit was estimated in five fruits collected from five different individuals.

Floral visitors, as well as their visiting behavior were recorded throughout the period of anthesis of S. sylvatica flowers, through direct observations mainly between 6:00 to 12:00 AM and between 2:00 to 5:00 PM, totaling 35 hours of observation (27 hours in the morning and eight in the afternoon). Additional records of visitors were made while walking on the trail. Hummingbirds were identified by direct visual observations and with the help of photographs taken during their visits. Identifications were then confirmed through comparison with illustrations in Grantsau (1988). The nomenclature of the birds followed the Brazilian Committee of Ornithological Records (2011). Measurements of hummingbirds' bill length (cf. Grantsau 1988) were taken from 24 specimens collected in five mist nets placed along trails in the study area. Insect visitors were collected with the aid of bottle killer and identified by specialists. For every visitor observed, the time and visiting behavior as well as its role in pollination of $S$. sylvatica were recorded. It was considered a pollinator the animal that contacted the anthers and stigma; and nectar 
thieves the ones that, during their visits, access the nectar without contacting these structures.

\section{Results}

In the first year of study, whose observations began in July 2005, individuals of $S$. sylvatica have been recorded flowering from July to September 2005 and in 2006, flowering occurred from March to August. Individuals may present one to five flowers open per day, and the flowers begin to open from the base to the apex of the inflorescence. On any given axil often occurs two or more flowers, which are tubular, zygomorphic, have no noticeable odor and have diurnal anthesis.

The flowers open early in the morning (ca. 6:00 AM) and remain open until senescence. The corolla is red, thick and has a hump-shaped gibbus in the lower face. Internally it is yellow with red spots and features lots of hairs on their margins (Figure 1). The average length of the corolla tube is $23.6 \pm 1.5 \mathrm{~mm}(\mathrm{n}=12)$ and the average diameter of the opening of the corolla is $6.0 \pm 1.0 \mathrm{~mm}(\mathrm{n}=12)$. The androecium is epipetalous, inclusive and usually consists of four stamens and a staminode, but in some flowers, the androecium consists of five stamens. The gynoecium has a bifid stigma and the ovary is inferior, unilocular, presenting numerous ovules with central placentation.

The flowers of $S$. sylvatica are protandrous, being functional male in the first four days of anthesis. The female phase begins on the fifth day. During the five days of observations the flowers were

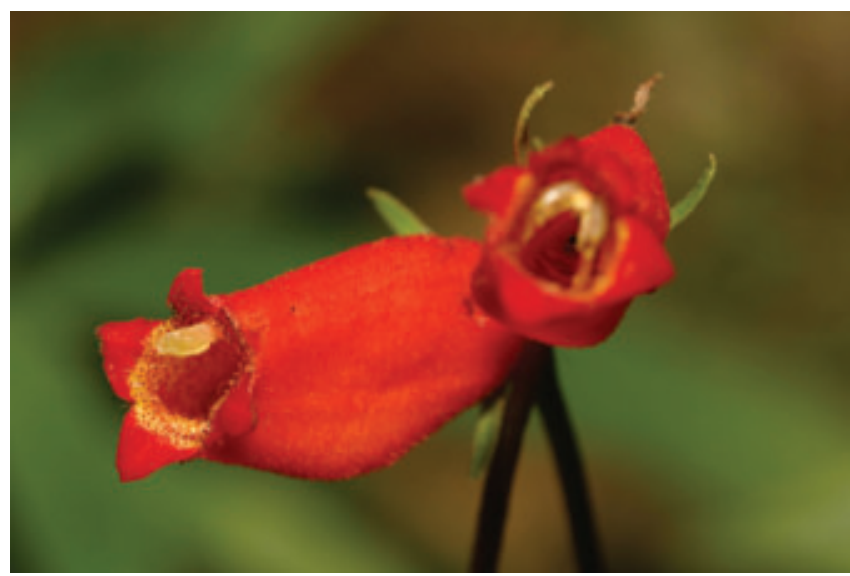

Figure 1. Frontal view of a flower of Seemania sylvatica (Kunth) Hanstein (Gesneriaceae). Note the presence of tricomes in the entrance of the corolla tube, and the enlargement (gibbus) in its middle portion. open, functional and live coloring. Flowers in the two phases can be found in the same individual. On the first day of anthesis, the anthers are positioned in the upper portion of corolla, close to the entrance of the floral tube (Figure 2a) with large amount of pollen available in massulas. In this phase, the stylus is shorter $(1.33 \pm 0.1 \mathrm{~mm}, \mathrm{n}=12)$ and the stigma is positioned above the anthers, closed and nonreceptive. On the second day the style undergoes a slight elongation $(1.66 \pm 0.17 \mathrm{~mm}, \mathrm{n}=12)$ toward the opening of the corolla. On the third day, the filaments begin to recede and the style extends a little more $(2.0 \pm 0.19 \mathrm{~mm}, \mathrm{n}=8)$. On the fourth day, the stigma is at the same level of the anthers $(2.3 \pm 0.06 \mathrm{~mm}, \mathrm{n}=3)$, but is not yet receptive. On the fifth day the flower becomes functionally female, the androecium withers and stamens and anthers assume a lower position, remaining retracted in the gibbus. The style elongates $(2.4 \pm 0.18 \mathrm{~mm}, \mathrm{n}=3)$ and protrudes out of the flower, being the stigma open and receptive at this stage (Figure $2 b$ ). The amount of pollen present in anthers decreased over the five days, during which the pollen viability did not vary significantly (ANOVA: $\mathrm{F}_{4,17}=3.23$, $\mathrm{p}=0.038$ ) and was about $99 \%$.

The nectary has a ring shape and is located above the ovary, around the style. The nectar is accumulated in the spaces between the threads at the bottom of the corolla. The concentration of nectar was higher in the afternoon $(17.09 \pm 6.49 \%, \mathrm{n}=14)$ compared to early morning $(9.37 \pm 4.58 \%, \mathrm{n}=38)(\mathrm{t}=-4.792, \mathrm{p}=0.000)$. However, the volume of nectar did not differ $(\mathrm{t}=-0.186, \mathrm{p}=0.854)$ between periods (morning: $6 \pm 4.9 \mu \mathrm{l}, \mathrm{n}=38$ and afternoon: $6.28 \pm 4.73 \mu \mathrm{l}, \mathrm{n}=14$ ). In the morning the average volume of nectar in the flowers varied significantly among different days (ANOVA: $\mathrm{F}_{5,32}=4.595, \mathrm{p}=0.003$ ), being the highest nectar volume recorded on the second day and the lowest in flowers with more than five days. On the other hand, there was no significant difference between the studied days (ANOVA: $\mathrm{F}_{5,32}=1.928, \mathrm{p}=0.117$ ) regarding mean solute concentration of nectar in the morning. Similarly, in the afternoon the average volume of nectar was not different between days (ANOVA: $\mathrm{F}_{2,11}=1.553$, $\mathrm{p}=0.255)$, but the average concentration of solutes in nectar varied significantly among flowers of different ages (ANOVA: $\mathrm{F}_{2,11}=14.039$, $\mathrm{p}=0.001$ ), being higher in the flowers of the third day (Figure 3 ).

The flowers of $S$. sylvatica were visited by hummingbirds (98.1\% of visits) and sporadically by a bee species and one butterfly (1.9\% of visits), and ants. Among the species of hummingbirds Phaethornis pretrei (Lesson \& Delattre, 1839) (bill length $=32.48 \pm 1.38 \mathrm{~mm}, \mathrm{n}=11$ ) and Thalurania furcata (Gmelin, 1788) females (bill length $=20.25 \pm 3.18 \mathrm{~mm}, \mathrm{n}=2$ ) were the most common (Table 1), while Amazilia versicolor (Vieillot, 1818) (bill length $=18 \mathrm{~mm}$, cf. Grantsau 1988),
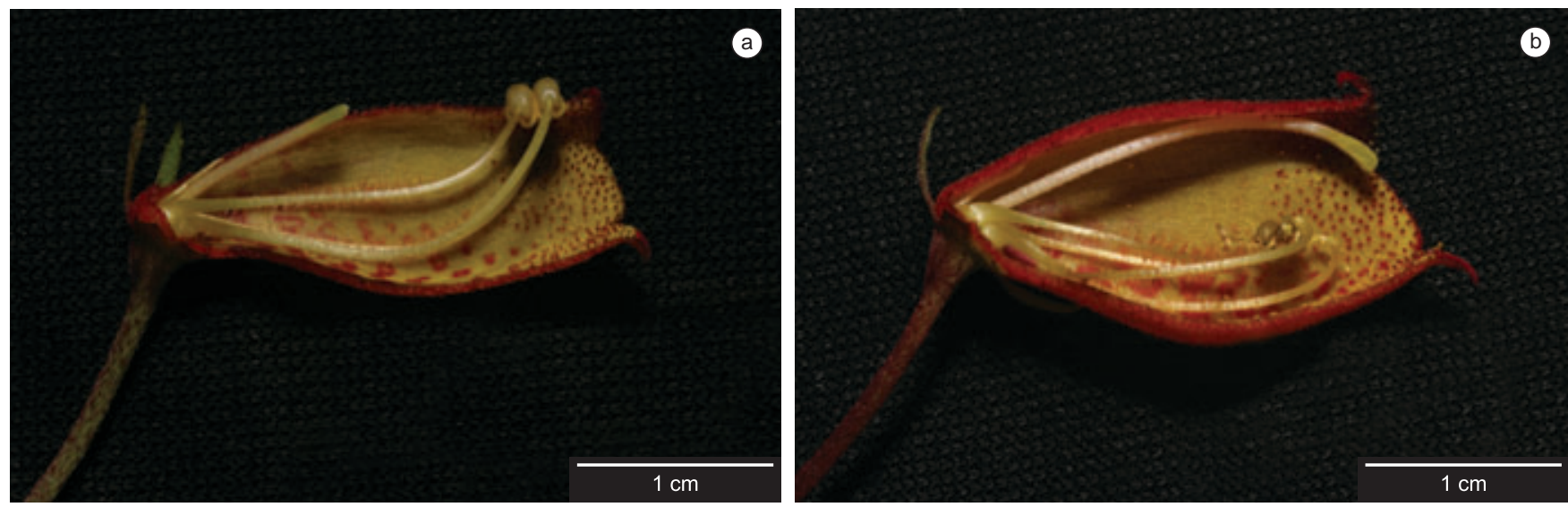

Figure 2. a) Longitudinal cut of a flower of Seemannia sylvatica (Kunth) Hanstein (Gesneriaceae) in its first day of anthesis; b) Longitudinal cut of a flower of $S$. sylvatica in its fifth day of anthesis. 
Hylocharis chrysura (Shaw, 1812) (bill length $=19.33 \pm 1.15 \mathrm{~mm}$, $\mathrm{n}=3$ ) and Thalurania furcata males (bill length $=18.73 \pm 2.82 \mathrm{~mm}$, $\mathrm{n}=6$ ) were infrequent visitors. Phaethornis pretrei was the most frequent visitor (Table 1) and visited the flowers throughout the day, most often in the morning, on rounds at regular intervals of 30 to 60 minutes. Females of T. furcata often visited flowers in patches of S. sylvatica and then alight on perches, attacking other hummingbirds that approached the flowers in their territory. The visits of the hummingbirds A. fimbriata, $H$. chrysura and males of $T$. furcata were less frequent and occasionally observed while walking the trail. All species of hummingbirds performed legitimate visits by introducing the bill in the corolla tube to sip nectar, contacting the reproductive structures of the flowers at this time. However, in some visits, both P. pretrei, and females of T. furcata accessed the nectar through holes made with its beaks at the base of the corolla, not contacting the stigma and anthers, acting therefore as casual thieves.

The butterfly Parides anchises orbygnianus (Lucas, 1852), the bee Ceratina chloris (Fabricius, 1804) and some unidentified ants were observed in flowers of S. sylvatica. Both P. anchises and C. chloris visited the flowers in search of nectar, with a low frequency of visits (Table 1). Parides anchises orbygnianus visited flowers in two ways: in the first, the butterfly landed on the upper portion of the flower and then inserted the proboscis into the opening of the corolla; in the second way, they landed in the lower portion of the corolla and then inserted the proboscis at its opening. However, due to floral morphology and position of reproductive structures of the flower of S. sylvatica in relation to the size and morphology of P. anchises orbygnianus, there was only contact between animal/ pollen/stigma in visits from the second kind, when those visitors landed at the bottom of the corolla. Due to its small size $C$. chloris did not contacted the reproductive elements of S. sylvatica flowers during their visits. Ants found in the flowers of $S$. sylvatica pierced the base of the corolla directly reaching the place where the nectar is accumulated, also not contacting the reproductive structures of flowers during visits.

According to results of the reproductive experiments, S. sylvatica is self-compatible. Except for the treatment of agamospermy, in all pollination experiments there was fruit formation (Table 2), with no significant difference (Pearson: $\mathrm{P}=0.08$ ) in the percentage of fruits produced between them. The fruits of $S$. sylvatica are denticidal capsules with an opening at its top and take about 60 days to mature. The seeds are tiny and ellipsoids and produced in an amount exceeding one thousand units per fruit.

\section{Discussion}

The flowering pattern of S. sylvatica, with a single episode of long duration in the year may be classified as annual (sensu Newstrom et al. 1994), a pattern commonly found in species of the tribe Sinningieae (Sanmartin-Gajardo \& Sazima 2004). According to the classification of Gentry (1974), the flowering strategy of S. sylvatica is the "steady state" and is associated with pollination by long life vectors, such as the hummingbirds.

The flowers of $S$. sylvatica have characteristics as red tubular corolla, diurnal anthesis, no odor, and reproductive organs distant from the site of nectar accumulation that are consistent with the ornithophilous syndrome (Faegri \& van der Pij1 1980). The bulging of the corolla (gibbus) of S. sylvatica, similar to that observed in Nematanthus fritschii Hoehne (Gesneriaceae), seems to be related to the enlargement of the visual stimulus to pollinators. Such a feature would also function to accommodate the anthers in the female phase of the flower, favoring the contact of the hummingbird with the stigma (Franco \& Buzato 1992). The morphology of the
Table 1. Floral visitors and its number and frequency of visits on flowers of Seemannia sylvatica (Kunth) Hanstein (Gesneriaceae) in the riparian forest of Salobrinha River, Serra da Bodoquena National Park, Mato Grosso do Sul.

\begin{tabular}{|c|c|}
\hline Visitor & $\begin{array}{c}\text { Number of } \\
\text { visits }(\%)\end{array}$ \\
\hline BIRDS - Trochilidae & - \\
\hline Phaethornis pretrei (Lesson \& Delattre, 1839) & $235(74.4)$ \\
\hline Thalurania furcata 9 (Gmelin, 1788) & $75(23.7)$ \\
\hline Thalurania furcata $\widehat{\partial}$ (Gmelin, 1788) & $*$ \\
\hline Amazilia versicolor (Vieillot, 1818) & $*$ \\
\hline Hylocharis chrysura (Shaw, 1812) & $*$ \\
\hline INSECTS & - \\
\hline LEPIDOPTERA - Papilionidae & - \\
\hline Parides anchises orbygnianus (Lucas, 1852) & $4(1.3)$ \\
\hline HYMENOPTERA - Anthophoridae & - \\
\hline Ceratina chloris (Fabricius, 1804) & $2(0.6)$ \\
\hline
\end{tabular}

*Only occasional visits recorded.

Table 2. Reproductive success (number of fruits produced/number of experimental flowers) in the treatments of agamospermy, spontaneous selfpollination, manual self-pollination, cross pollination and natural pollination in Seemannia sylvatica (Kunth) Hanstein (Gesneriaceae) in the riparian forest of Salobrinha River, Serra da Bodoquena National Park, Mato Grosso do Sul.

\begin{tabular}{lc}
\hline Treatments & $\begin{array}{c}\text { Reproductive success \% } \\
\text { (fruits/flowers) }\end{array}$ \\
\hline Agamospermy & $0(0 / 10)$ \\
Spontaneous self pollination & $27.2(6 / 22)$ \\
Manual self pollination & $47.4(9 / 19)$ \\
Cross pollination & $50.0(9 / 18)$ \\
Natural pollination & $66.7(14 / 21)$ \\
\hline
\end{tabular}
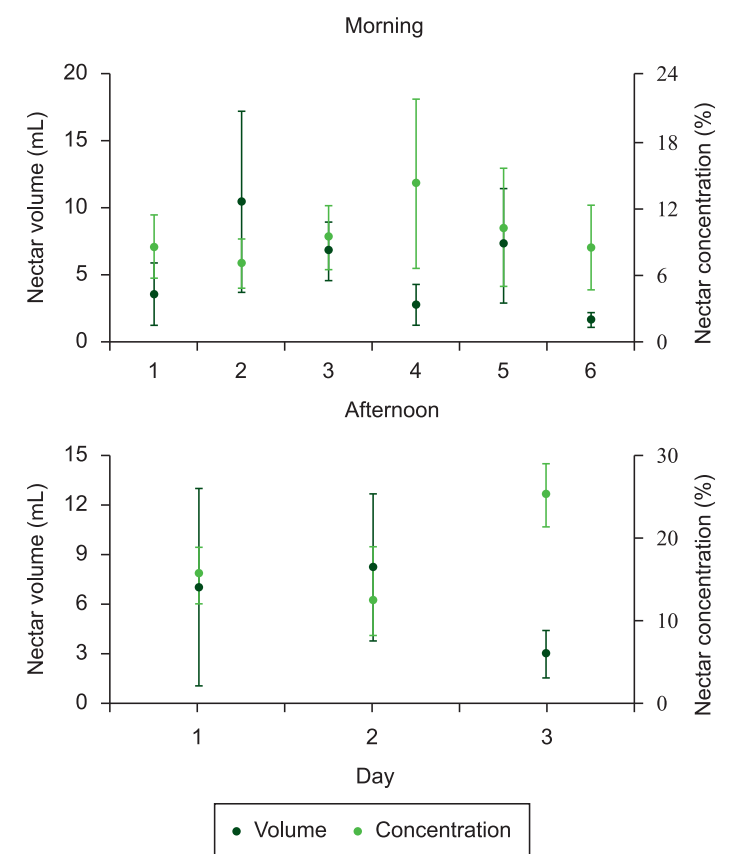

Figure 3. Variation on mean volume $(\bullet)$ and concentration $(\bullet)$ of solutes in nectar in flowers of Seemannia sylvatica (Kunth) Hanstein (Gesneriaceae) of different ages $(1=$ first day flowers, $2=$ second day flowers, $3=$ third day flowers, $4=$ fourth day flowers, $5=$ fifth day flowers, $6=$ flowers with more than five days), in morning and afternoon periods, in the riparian forest of Salobrinha River, Serra da Bodoquena National Park, Mato Grosso do Sul. Full bars represent standard deviations for nectar concentration, and dashed lines represent the deviations for volume. 
reproductive structures and the changes of position during anthesis in S. sylvatica are similar to those reported for other neotropical species of Gesneriaceae (Wiehler 1983, Steiner 1985, Franco \& Buzato 1992).

The flowers of $S$. sylvatica last more than five days under natural conditions. In this study we could not verify the exact duration of the flowers, once the fieldwork was conducted over five consecutive days per month, period in which the followed flowers were still functional, brightly colored and attached to the plant. However, in individuals of $S$. sylvatica which were transferred to an urban garden and kept in vases under natural conditions, the flowers lasted 10 to 20 days, being brightly colored and apparently functional during all this period (personal observation), but floral biology was not accompanied. Thus, the flowers of $S$. sylvatica seem to last much more than the recorded in other species of Gesneriaceae, in which flowers usually last between two (Steiner 1985) and five days (Franco \& Buzato 1992, SanmartinGajardo \& Sazima 2005a, Gao et al. 2006).

The highest concentration of nectar of $S$. sylvatica in the afternoon may be related to its evaporation, since the measurements performed in the afternoon correspond to the volume of nectar accumulated over the day (s) until the measure. During part of the day, sunlight falls directly on the studied patches of $S$. sylvatica, raising the local temperature, what could cause evaporation of nectar. The fact that the highest volume of nectar have been recorded in the morning of second day flowers, and the greater concentration on fourth day flowers may suggest that $S$. sylvatica is more attractive to their pollinators in the early days of their anthesis. However, since monitoring of the flowers was done only during the first five days of anthesis, further studies evaluating the nectar production throughout the anthesis period are needed.

Phaethornis pretrei was the most important pollinator of S. sylvatica in the riparian forest of Rio Salobrinha, since it was the most frequent visitor, mostly performing legitimate visits. Moreover, this hummingbird present the "trapline" foraging behavior (sensu Feinsinger \& Colwell 1978), a strategy that can increase gene flow (Linhart 1976), since P. pretrei includes flowers from many individuals in different patches in its foraging route. As well as $P$. pretrei, other species of the subfamily Phaethornithinae are important pollinators of species of Gesneriaceae as Ramphodon naevius (Dumont, 1818) in Nematanthus fritschii Hoehne (Franco \& Buzato 1992), Phaethornis pretrei and P. eurynome (Lesson 1832) in Sinningia gigantifolia Chautems, Vanhouttea hilariana Chautems and V. brueggeri Chautems (Sanmartin-Gajardo \& Sazima 2005a). Apparently the pollination of these species of Gesneriaceae by Phaethornithinae hummingbirds is associated with their habitat of occurrence. When these plants occur in forested areas and near streams, habitats commonly used by Phaethornithinae hummingbirds (Stiles 1978, 1981, Cotton 1998), they usually are pollinated by them (Sanmartin-Gajardo \& Sazima 2005a).

During visits to flowers of $S$. sylvatica, females of Thalurania furcata often acted as territorialists. This foraging behavior may decrease pollen flow between individuals, since the hummingbird visited only flowers in the patch (es) included in its territory (Feinsinger \& Colwell 1978). The observation of territorial behavior in females of $T$. furcata differs from that recorded for an Atlantic congener (T. glaucopsis) during visits to flowers of Psychotria nuda Cham \& Schltdl.- Rubiaceae (Castro \& Araujo 2004) and Vriesea rodigasiana E. Morren - Bromeliaceae (Rocca de Andrade 2006). In those species, the males of T. glaucopis presented aggressive and territorial behavior, while females foraged in "trap lines". The territorial behavior observed for females of T. furcata may be related to the large number of flowers in a given patch of S. sylvatica (in the study area there were patches of individuals of S. sylvatica bearing up to 190 flowers), which would make it advantageous to establish territories (Wolf et al. 1976, Arizmendi \& Ornelas 1990, Cotton 1998). Moreover, during the flowering of $S$. sylvatica, males of $T$. furcata occurred at low frequency in the area and visited mainly flowers of Ruellia angustiflora (Ness) Lindau ex Rambo (Acanthaceae) (personal observation).

The frequency of visits of the butterfly Parides anchises and of the bee Ceratina chloris to flowers of S. sylvatica was low, as was also recorded for these species on flowers of Ruellia brevifolia (Pohl) Ezcurra (Acanthaceae) in semideciduous forest of southeastern Brazil (Sigrist \& Sazima 2002). Similar to the recorded in S. sylvatica, $P$. anchises was considered occasional pollinator of flowers of $R$. brevifolia due to its low frequency in the flowers $(<10 \%)$, although this butterfly contacts the reproductive structures of flowers during their visits. In that study, the bee $C$. chloris, as in $S$. sylvatica, was considered a robber, since it does not contacted the reproductive structures of the flower during visits (Sigrist \& Sazima 2002). In Drymonia surrelata (Poepp.) Wiehler and Sinningia schiffneri Fritsch these bees visited flowers only in the male phase to collect pollen (Steiner 1985, Sanmartin-Gajardo \& Sazima 2004). A species of Ceratina was observed inside the corolla tube robbing nectar in Sinningia "canastrensis" Chautems but not contacted the stamens and stigmas of the flower due to its small size (Sanmartin-Gajardo $\&$ Sazima 2004). Thus, based on data from this study and the studies cited above, species of Ceratina seem to be common visitors and thieves on species of Gesneriaceae.

The occurrence of protandry is common in species of Gesneriaceae (Wiehler 1983, Steiner 1985, Franco \& Buzato 1992, Lara \& Ornelas 2002, Sanmartin-Gajardo \& Sazima 2005b, Gao et al. 2006) and is a mechanism that prevents self-pollination. Although there is a temporal separation between its reproductive structures, $S$. sylvatica is self compatible, a phenomenon common to other species of this family (Steiner 1985, Sanmartin-Gajardo \& Sazima 2004, SanmartinGajardo \& Sazima 2005a, Gao et al. 2006). This characteristic, coupled with the fact that in the same individual flowers in female and male phases are present, may promote geitonogamy (Percival 1965). However, the trapline visiting behavior of the main pollinator of this species promotes the pollen dispersal between different individuals, facilitating gene flow (Stiles 1975, Feinsinger 1983).

In $S$. sylvatica, despite protandry, there was fruit formation by spontaneous self-pollination $(27.2 \%)$, which is rare in this family (Sanmartin-Gajardo \& Freitas 1999). This may have occurred in S. sylvatica due to the large amount of pollen produced and by the fact that it's easily detached from the anthers of floral buds by any movement caused by visitors or even by wind. This pollen may have been accidentally placed on the yet non-receptive stigma of the same flower, remaining there until the onset of the female phase, when fertilized ovules. This hypothesis is supported by high pollen viability in the female phase. Another possible hypothesis is based on the fact that in the female phase, starting in the fifth day of anthesis, it was observed some flowers presenting very long and curved stigmas, with anthers that have not yet fully recovered in the gibbus. At this time the stigma may have contacted the pollen remaining in anthers. However, under natural conditions, due to the removal of pollen by floral visitors, it hardly should occur.

The protandry, coupled with the pattern of nectar production in S. sylvatica, characterized by low volume and solute concentration, which induces the pollinators to visit different flowers in a given foraging circuit, act to maximize the likelihood of cross-pollination. Moreover, the high proportion of fruit set by autogamy is an important strategy considering that $S$. sylvatica is visited by few species, being pollinated mainly by $P$. pretrei. Therefore, in the absence of these visitors, fruit formation can be ensured. 


\section{Acknowledgements}

To Gabriel Mello and André Victor Lucci Freitas for identification of Ceratina chloris and Parides anchises orbygnianus respectively; to Andréa O. Araújo for identification of Seemannia sylvatica; to Rogério Rodrigues Faria and Éder A. Doná for helping in the field work; to José Carlos Nunes Nascimento, owner of Rancho Branco farm and their employees for permission to access the study area; to Maria Rosângela Sigrist and Ângela L. B. Sartori for suggestions in the early version of the manuscript. To FUNDECT (Fundação de Apoio ao Desenvolvimento do Ensino, Ciência e Tecnologia do Estado de Mato Grosso do Sul) for financial support, and to CNPq (Conselho Nacional de Desenvolvimento Científico e Tecnológico) for the grants to Eduardo Camargo (IC - Process 103950/2005-2) and Licléia da Cruz Rodrigues (DTI-M - Process 310196/2005-1).

\section{References}

ARIZMENDI, M.C. \& ORNELAS, J.F. 1990. Hummingbirds and their floral resources in a tropical dry forest in Mexico. Biotropica 22(2):172-180. http://dx.doi.org/10.2307/2388410

BRASIL. 1997. Ministério do Meio Ambiente, dos Recursos Hídricos e da Amazônia Legal. Plano de Conservação da Bacia do Alto Paraguai PCBAP. Brasília, v.2.

CASTRO, C.C. DE \& ARAUJO, A. C. 2004. Distyly and sequential pollinators of Psychotria nuda (Rubiaceae) in the Atlantic rain forest, Brazil. Plant Syst. Evol. 244:131-139. http://dx.doi.org/10.1007/s00606-003-0036-8

COMITÊ BRASILEIRO DE REGISTROS ORNITOLÓGICOS CBRO. 2011. Listas das aves do Brasil. 10nd ed. http://www.cbro.org. br (Último aceso em 11/2011).

COTTON, P.A. 1998. The hummingbird community of a lowland Amazonian rainforest. IBIS 140:512-521. http://dx.doi.org/10.1111/j.1474919X.1998.tb04613.x

DAFNI, A., KEVAN, P.G. \& HUSBAND, B.C. 2005. Practical pollination biology. Environquest Ltd. Ontario.

ENDRESS, P.K. 1994. Diversity and evolutionary biology of tropical flowers. Cambrigde Press, Cambridge.

FEINSINGER, P. \& COLWELL, R.K. 1978. Community organization among Neotropical nectar-feeding birds. Am. Zool. 18:779-795.

FEINSINGER, P. 1983. Variable nectar secretion in Heliconia species pollinated by hermit hummingbirds. Biotropica 15(1):48-52. http://dx.doi. org/10.2307/2387998

FAEGRI, K. \& VAN DER PIJL, L. 1980. The principles of pollination ecology. Pergamon Press, Oxford.

FRANCO, A.L.M. \& BUZATO, S. 1992. Biologia floral de Nematanthus fritschii (Gesneriaceae). Rev. Bras. Biol. 52(4):661-666.

GALETTO, L. \& BERNARDELLO, G. 2005. Rewards in flowers: Nectar. In: Practical Pollination Biology (A. Dafni, Kevan P.G. \& B.C. Husband, eds.). Enviroquest Ltd., 590p.

GRANTSAU, R. 1988. Os beija-flores do Brasil. Editora Expressão e Cultura, Rio de Janeiro. 233p.

GAO, J.Y., REM, P.Y., YANG, Z.H., LI, Q.J. 2006. The pollination ecology of Paraboea rufescens (Gesneriaceae): a buzz-pollinated tropical herb with mirror-image flowers. Ann. Bot.-London 97(3):371-376. PMid:16371444. PMCid:2803634. http://dx.doi.org/10.1093/aob/mcj044

GENTRY,A.H. 1974. Coevolutionary patterns in Central American Bignoniaceae. Ann. Mo. Bot. Gard. 61:728-759. http://dx.doi.org/10.2307/2395026

KEVAN, P.G., CLARK, E.A. \& THOMAS,V.G. 1990. Insect pollination and sustainable agriculture. Am. J. Alternative Agr. 5:12-22. http://dx.doi. org/10.1017/S0889189300003179

KÖPPEN, W. 1948. Climatologia. Fondo de Cultura Económica, México.

LARA, C. \& ORNELAS, J.F. 2002. Effects of nectar theft by flower mites on hummingbird behavior and the reproductive success of their host plant, Moussonia deppeana (Gesneriaceae). Oikos 96(3):470-480. http://dx.doi. org/10.1034/j.1600-0706.2002.960309.x

LINHART, Y.B. 1976. Ecological and behavioral determinants of pollen dispersal in hummingbird-pollinated Heliconia. Am. Nat. 107:511-523.
NEWSTROM, L.E., FRANKIE, G.W., BAKER, H.G. 1994. A new classification for plant phenology based on flowering patterns in lowland tropical rain forest trees at La Selva, Costa Rica. Biotropica 26(2):141159. http://dx.doi.org/10.2307/2388804

PERCIVAL, M. 1965. Floral Biology. Pergamon Press.

RADFORD, A.E., DICHINSON, W.C., MASSEY, J.R. \& BELL, C.R. 1974. Vascular plant systematic. Harper \& Row Publishers, New York.

ROALSON, E.H., BOGGAN, J.K. \& LAUREENCE, E.S. 2005. Reorganization of tribal and generic boundaries in the Gloxinieae (Gesneriaceae: Gesnerioideae) and the description of a new tribe in the Gesnerioideae, Sphaerorrhizeae. Selbyana 25(2):225-238.

ROCCA DE ANDRADE, M.A. 2006. Recurso floral para aves em uma comunidade de Mata Atlântica de encosta: sazonalidade e distribuição vertical. Tese de doutorado, Universidade Estadual de Campinas, Campinas.

SANMARTIN-GAJARDO, I. \& FREITAS, L. 1999. Hummingbird pollination in Besleria longimucronata Hoehne (Gesneriaceae) in southeastern Brazil. Biociências 7:13-24.

SANMARTIN-GAJARDO, I. \& SAZIMA, M. 2004. Non-Euglossine bees also function as pollinators of Sinningia species (Gesneriaceae) in southeastern Brazil. Plant Biology 6(4):506-512. PMid:15248134. http:// dx.doi.org/10.1055/s-2004-820979

SANMARTIN-GAJARDO, I. \& SAZIMA, M. 2005a. Espécies de Vanhouttea Lem. e Sinningia Nees (Gesneriaceae) polinizadas por beija-flores: interações relacionadas ao hábitat da planta e ao néctar. Rev. Bras. Bot. 28(3):441-450. http://dx.doi.org/10.1590/S010084042005000300003

SANMARTIN-GAJARDO, I. \& SAZIMA, M. 2005b. Chiropterophily in Sinningieae (Gesneriaceae): Sinningia brasiliensis and Paliavana prasinata are bat-pollinated, but $P$. sericiflora is not. Not yet? Ann. Bot.London 95(7):1097-1103. PMid:15797896. http://dx.doi.org/10.1093/ aob/mci124

SAZIMA, M., VOGEL, S., PRADO, A.L., FRANZ, G., OLIVEIRA, D.M. \& SAZIMA, I. 2001. The sweet jelly of Combretum lanceolatum flowers (Combretaceae): a cornucopia resource for bird pollinators in the Pantanal, western Brazil. Plant Syst. Evol. 227:195-208. http://dx.doi.org/10.1007/ s006060170048

SIGRIST, M.R. \& SAZIMA, M. 2002. Ruellia brevifolia (Pohl) Ezcurra (Acanthaceae): fenologia da floração, biologia da polinização e reprodução. Rev. Bras. Bot. 25:35-42. http://dx.doi.org/10.1590/S010084042002000100006

SCREMIN-DIAS, E., POTT, V.J., HORA, R.C. \& SOUZA, P.R. 1999. Nos jardins submersos da Bodoquena: guia para identificação de plantas aquáticas de Bonito e região. Ed. UFMS, Campo Grande.

STEINER, K. E. 1985. The role of nectar and oil in the pollination of Drymonia serrulata (Gesneriaceae) by Epicharis Bees (Anthophoridae) in Panama. Biotropica 17(3):217-229. http://dx.doi.org/10.2307/2388222

STILES, F.G. 1975. Ecology, flowering phenology, and hummingbird pollination of some Costa Rican Heliconia species. Ecology 56:285-301. http://dx.doi.org/10.2307/1934961

STILES, F.G. 1978. Temporal organization of flowering among the hummingbird food plants of a tropical wet forest. Biotropica 10(3):194-210. http:// dx.doi.org/10.2307/2387905

STILES, F.G. 1981. Geographical aspects of bird-flower coevolution, with particular reference to Central America. Ann. of the Missouri Bot. Garden 68:323-351. http://dx.doi.org/10.2307/2398801

SOUZA, V.C. \& LORENZI, H. 2005. Botânica Sistemática: guia ilustrado para identificação das famílias de Angiospermas da flora brasileira, baseado em APG II. Instituto Plantarum, Nova Odessa.

WIEHLER, H. 1976. A report on the classification of Achimenes, Eucodonia, Seemannia, Goyazia, and Anetanthus (Gesneriaceae). Selbyana 1:374-404

WIEHLER, H. 1983. A synopsis of the neotropical Gesneriaceae. Selbyana 6:1-219.

WOLF, L.L., STILES, F.G. \& HAINSWORTH, F.R. 1976. Ecological organization of a tropical, highland hummingbird community. J. Animal Ecol. 32:349-379. http://dx.doi.org/10.2307/3879 